\title{
Analogias e metáforas no ensino de Física Moderna apresentadas nos li- vros didáticos aprovados pelo PNLD $2018^{+*}$
}

\author{
Felipe Augusto Kopp ${ }^{1}$ \\ Voltaire de Almeida ${ }^{1}$ \\ Universidade de Santa Cruz do Sul \\ Santa Cruz do Sul - RS
}

\section{Resumo}

Este artigo investiga a presença de analogias e metáforas em capítulos de Física Moderna nos livros didáticos indicados pelo Guia de Livros Didáticos - PNLD 2018. Com base nos estudos linguísticos mais atuais, tenta-se estabelecer uma distinção conceitual entre essas duas figuras de linguagem para que elas possam ser melhor aproveitadas no ensino de Física. Para a coleta e registro dos dados, utiliza-se a análise de conteúdos proposta por Bardin (2002), enquanto que para a classificação das ocorrências é utilizada uma versão adaptada daquela proposta por Curtis e Reigeluth (1984). Os resultados obtidos, tanto numéricos quanto qualitativos, evidenciam as características opostas entre analogias e metáforas. Ambas aproximam informações familiares ou já conhecidas (veículo) de informações novas (alvo), mas a analogia faz isso aproximando coisas que pertencem a domínios com características comuns, enquanto a metáfora o faz aproximando coisas que pertencem a domínios muito distintos. Didaticamente, as analogias permitem fazer comparações por meio de semelhanças ou diferenças, o que é fundamental para a explicação de conceitos de Física Moderna. Já as metáforas podem ajudar a aproximar conceitos concretos de abstratos, mas isso é feito, em geral, de forma mais simples, o que requer um cuidado maior por parte dos autores de livros didáticos e dos professores que os utilizam.

\footnotetext{
${ }^{+}$Analogies and metaphors on chapters of Modern Physics in textbooks approved by the PNLD 2018

* Recebido: agosto de 2018. Aceito: fevereiro de 2019.

${ }^{1}$ E-mails: felipekopprpg@hotmail.com; voltaire@unisc.br
} 
Palavras-chave: Analogias; Metáforas; Livro didático; Física Moderna; Ensino de Física.

\begin{abstract}
This paper investigates the presence of analogies and metaphors on chapters of Modern Physics in textbooks indicated by the Guia de Livros Didaticos - PNLD 2018. Based on the most current language studies, there is an attempt to establish a conceptual distinction between these two figures of speech in order to a better use on Physics Education. The content analysis proposed by Bardin (2002) is used for data collection and registration and an adapted version of classification created by Curtis and Reigeluth (1984) is used for the classification of the occurrences. The numerical and qualitative data show the opposite characteristics between analogies and metaphors. Both compare familiar or already known information (vehicle) to new information (target), but the analogy does that with things that belong to the same domains while the metaphor does that with things that belong to different ones. Analogies is a useful tool to compare similarities and differences, which is very important to teaching concepts of Modern Physics. On the other hand, metaphors may make comparisons through concrete to abstract concepts, however this is done on a simplest form, hence, it requires more attention by authors of textbooks and teachers who use them.
\end{abstract}

Keywords: Analogies; Metaphors; Textbooks; Modern Physics;Physics Education.

\title{
I. Introdução
}

Estudos que discutem o papel da linguagem na produção e divulgação do conhecimento científico ganharam força após a virada linguística no início do século XX. Esses estudos, com o tempo, chegaram também ao campo do ensino de ciências e, mais recentemente, à análise de livros didáticos. No Brasil, a investigação da linguagem utilizada nos livros didáticos de ciências ganhou força após a aprovação da Lei de Diretrizes e Bases da Educação Nacional (LDB) de 1996. Outro fator foi a criação, no mesmo ano, de critérios explícitos de avaliação desses livros por parte do Ministério da Educação (MEC), o que significou um avanço nos seus programas: Programa Nacional do Livro Didático (PNLD); Programa Nacional do Livro Didático para o Ensino Médio (PNLEM); Programa Nacional do Livro Didático para Alfabetização de Jovens e Adultos (PNLA). 
Entre os assuntos mais comuns no estudo da linguagem na produção, divulgação e ensino de ciências está o das figuras de linguagem. No ensino em geral, é muito comum se fazer uso dessas figuras para aproximar o conhecimento prévio do aluno do conhecimento estudado em sala de aula. No campo das ciências exatas e naturais isso não é incomum, uma vez que o conhecimento científico às vezes está bastante distanciado daquele com o qual o estudante chega à escola. $\mathrm{O}$ uso, por exemplo, de analogias e metáforas pode diminuir essa distância, aproximando conceitos familiares de conceitos mais abstratos ou ainda comparando diferentes fenômenos físicos, equações etc.

O presente estudo investiga o uso dessas analogias e metáforas nos capítulos de Física Moderna dos livros didáticos de Física do ensino médio, já que é o campo do saber menos familiar ao estudante, por tratar de fenômenos que, em geral, ocorrem no plano do muito pequeno (ao nível subatômico) ou do muito grande (no nível astronômico). São analisados os referidos capítulos nas doze coleções de Física recomendados pelo Guia de Livros Didáticos - PNLD 2018, do Ministério da Educação (BRASIL, 2017a).

A metodologia adotada para a coleta e análise dos dados foi a análise de conteúdos proposta por Bardin (2002) e os critérios para a classificação das ocorrências de analogias e metáforas foi o de Curtis e Reigeluth (1984).

Abaixo, a nomenclatura dos livros didáticos utilizada para este trabalho:

Tabela 1 - Nomenclatura adotada para as coleções didáticas.

\section{Nomenclatura}

adotada

FIS 1 BARRETO, B.; XAVIER, C. Física aula por aula: $3^{\circ}$ ano. 3. ed. São Paulo: FTD, 2016.

FIS 2 BISCUOLA, G. J.; VILLAS BÔAS, N.; DOCA, R. H. Física. 3. ed. São Paulo: Saraiva, 2016. v. 3.

FIS 3 BONJORNO, V. et al. Física: $3^{\circ}$ ano. 3. ed. São Paulo: FTD, 2016.

FIS 4 GASPAR, A. Compreendendo a física. 3. ed. São Paulo: Ática, 2016. v. 3.

FIS 5 GONÇALVES FILHO, A.; TOSCANO, C. Física: interação e tecnologia. 2. ed. São Paulo: Leya, 2016. v. 3.

FIS 6 GUIMARÃES, O.; PIQUEIRA, J. R.; CARRON, W. Física. 2. ed. São Paulo: Ática, 2016. v. 3

FIS 7 LUZ, A. M. R.; ÁlVARES, B. A.; GUIMARÃES, C. G. Física: contexto \& aplicações: ensino médio. 2. ed. São Paulo: Scipione, 2016. v. 3.

FIS 8 MARTINI, G. et al. Conexões com a física. 3. ed. São Paulo: Moderna, 2016. v. 3.

FIS 9 PIETROCOLA, M. et al. Física em contexto: $3^{\circ}$ ano do ensino médio. São Paulo: Editora do Brasil, 2016. 
FIS 10 TORRES, C. M. A. et al. Física: ciência e tecnologia. 4. ed. São Paulo: Moderna, 2016. v. 3.

FIS 11 VÁLIO, A. B. M. et al. Ser protagonista: física: $3^{\circ}$ ano do ensino médio. 3. ed. São Paulo: Edições SM, 2016.

FIS 12 YAMAMOTO, K.; FUKE, L. F. Física para o ensino médio. 4. ed. São Paulo: Saraiva, 2016. v. 3.

Fonte: Elaborada pelos autores.

\section{Justificativa}

Metáforas e analogias são instrumentos comuns da linguagem humana. Os usos que se fazem delas, no cotidiano, são praticamente imperceptíveis, pois, na maioria das vezes, não são compreendidas como tais (LAKOFF; JOHNSON, 2003; SARDINHA, 2007; MOURA, 2012). Quando se ouvem frases como "nenhum homem é uma ilha" (John Donne), "tempo é dinheiro" (dito popular), "o casamento é uma empresa e você precisa administrá-la" (Edir Macedo) e "o futebol é uma caixinha de surpresas" (Benjamim Wright), compreende-se o sentido de tais expressões metafóricas tão rápido quanto se diante de expressões literais (PYNTE et al., 1996). É mesmo necessário um segundo momento para se perceber que se tratam de metáforas (HOFFMAN; KEMPER, 2009) 2.

Por ser tão banal e corriqueira, muitas vezes, professores e autores de livros didáticos utilizam desses recursos de maneira indiscriminada - ainda que bem-intencionada - para ilustrar ou mesmo facilitar o conhecimento científico que se pretendem ensinar aos estudantes. Porém, sem os devidos cuidados, como o de se explicitar o uso desses recursos ou de apresentar os limites das comparações feitas, eles podem causar diversos problemas de aprendizagem, especialmente de conceitos científicos.

Além do mais, as explicações por meio de analogias e metáforas podem vir carregadas de imagens extraídas do senso comum ou de estereótipos sociais, afastando ainda mais o entendimento do conceito científico esperado, podendo promover o reforço de concepções alternativas. Por isso, cresceu a necessidade de se estudar os usos desses recursos linguísticos em salas de aula ou em livros didáticos a partir das décadas de 1980 e 1990 no Brasil e no mundo (MONTEIRO; JUSTI, 2000; DUARTE, 2005; FERREIRA; GONÇALVES, 2013; MOZZER; JUSTI, 2015).

\footnotetext{
2 Durante muitos séculos, a teoria mais aceita era a de que as analogias e as metáforas eram compreendidas primeiro literalmente e depois em seu sentido figurado. Ou seja, quando diante da expressão "o futebol é uma caixinha de surpresas", o cérebro primeiro processaria a informação literal - de que o futebol é, realmente, uma caixa contendo algum tipo de objeto desconhecido - e, só depois, seriam buscados outros sentidos possíveis, como, por exemplo, ele ser imprevisível. Essa concepção foi completamente descartada com os estudos neurolinguísticos mais modernos, que comprovaram exatamente o contrário: primeiro se compreende o sentido metafórico e só com um esforço maior é possível apreender o sentido literal.
} 
Ferreira (2011) localizou, a partir de coleta de dados do Currículo Lattes - que é restrito a pesquisadores que atuam no Brasil -, 426 publicações sobre analogias, 51\% delas na área de educação.

A investigação sobre o uso de analogias e metáforas especificamente em livros didáticos de Física ganhou maior atenção no Brasil após os meados da década de 1990, impulsionada pela aprovação da LDB em 1996 e pela adoção, por parte do MEC, de critérios de avaliações dos livros didáticos no mesmo ano. Leite, Garcia e Rocha (2011) identificaram 4 artigos sobre o tema nas 6 principais revistas de ciências do país entre os anos de 1996 e 2000. Já Silva e Almeida (2009) localizaram 11 artigos sobre o uso de linguagem analógica em Física ${ }^{3}$ em 8 revistas brasileiras entre os anos de 1979 e 2007, sendo 8 deles após 1996 e 6 após 2000. Na pesquisa bibliográfica do trabalho aqui apresentado, foram encontrados, em revistas nacionais publicadas entre 2000 e 2017, 9 artigos sobre analogias e/ou metáforas em livros didáticos de Física, além de alguns artigos publicados por brasileiros em revistas estrangeiras e mais uma dezena de artigos publicados em anais de eventos. O que comprova o crescente interesse pelo tema.

Apesar disso, percebeu-se que a pesquisa na área possui algumas limitações e dificuldades. A primeira delas diz respeito ao corpus de análise. Apenas dois artigos fazem uma análise de todas as coleções do Guia de Livros Didáticos do MEC na área de Física: um com as obras do PNLEM 2009 (SILVA; MARTINS, 2010) ${ }^{4}$, com livros válidos entre 2009 e 2011 e outro com as obras do PNLD 2012 (ROSA; CÓTICA; PEREIRA, 2016), válidos entre 2012 e 2014. Não há, até a presente data, nenhum artigo sobre as obras do PNLD 2015, válidos entre 2015 e 2017, muito menos sobre o recém lançado PNLD 2018, para 2018-2020.

O limitado número de corpora consequentemente dificulta a comparação dos resultados com aqueles já obtidos por outros pesquisadores. Não há nem mesmo como comparar os resultados e cruzar os dados dos dois artigos citados acima, pois o primeiro apresenta os números de analogias e metáforas encontrados em todas as coleções didáticas, enquanto o outro apresenta apenas em capítulos de eletricidade. Situação parecida ocorre com os demais artigos. Ora analisam um número limitado de livros, sem apresentar justificativa para tal escolha, ora restringem a investigação a um certo conteúdo (como eletricidade, mecânica etc.), sem também explicar as justificativas para tal opção. Para amenizar essas dificuldades e permitir uma comparação coerente com resultados já publicados, neste trabalho foram estabelecidos dois critérios: I) analisar todas as coleções de Física recomendadas pelo Guia de Livros Didáticos - PNLD 2018, por não ter sido encontrada razão para restringir esse número; II) delimitar a um conteúdo com base em estatísticas já levantadas por pesquisas anteriores.

Essas estatísticas foram encontradas em Zambon, Piccini e Terrazzan (2009) que, apesar de reduzirem sua investigação a poucos livros didáticos de Física, conseguiram provar

\footnotetext{
${ }^{3}$ Não apenas em livros didáticos.

4 O artigo diz ser do PNLEM 2007, mas não existe tal publicação. Fazendo o cruzamento de dados, conclui-se que seja mesmo o PNLEM 2009.
} 
que o maior número de ocorrência de analogias aparece nos capítulos de Eletromagnetismo (33,3\%), Física Moderna (28,5\%) e Óptica (28,5\%). Como existe uma publicação recente sobre as analogias e metáforas em capítulos que tratam de eletricidade (ROSA; CÓTICA; PEREIRA, 2016), optou-se por restringir a análise aos capítulos referentes ao conteúdo de Física Moderna (ou equivalente).

Por fim, outra dificuldade encontrada foi quanto à definição de analogias e de metáforas e quanto a suas classificações, o que altera significativamente o número de ocorrências possíveis de serem encontradas durante a análise. Ainda que o ideal fosse criar, como propõem Curtis e Reigeluth (1984) e também Thiele e Treagust (1994), uma classificação a posteriori, ou seja, agrupar as ocorrências de analogias e de metáforas em categorias e formular uma definição conceitual apenas após a coleta de um número significativo de dados, preferiuse utilizar uma classificação já existente e largamente aplicada em outros trabalhos (ver 3.2).

\section{Fundamentação Teórica}

\section{III.1 Analogias e metáforas}

Existem centenas de estudos, nos mais diversos campos do conhecimento, acerca das analogias e metáforas, que vão desde os postulados de Aristóteles, no século IV a.C., às pesquisas neurolinguísticas e computacionais mais atuais. Godoy (2002, p. 2-3) identifica oito perspectivas sobre as quais são abordadas as analogias e metáforas atualmente: I) perspectiva epistemológica; II) perspectiva de comunicação interdisciplinar; III) perspectiva de aprendizagem; IV) perspectiva cognitiva; V) perspectiva computacional; VI) perspectiva neurológica; VII) perspectiva histórica e cultural; VIII) perspectiva retórica.

Ao se explorar esses estudos, percebem-se pelo menos três diferentes definições para esses recursos linguísticos: a) comparação de termos novos com outros já conhecidos; b) relação de semelhança ou dependência entre objetos diferentes; c) prolongamento de uma comparação, em que se estabelecem múltiplas relações (FERREIRA; GONÇALVES, 2013). O que é consenso é que tanto a analogia quanto a metáfora são maneiras de se estabelecer proximidades entre coisas distintas, relacionando-as, seja por meio de características comuns ou díspares. A diferença entre elas reside no modo como essa aproximação é feita.

Às vezes, os termos analogia e metáfora são tomados como iguais, noutras, como conceitos distintos. Neste trabalho, analogias e metáforas serão diferenciadas com base nas suas estruturas e funcionalidades apenas com o propósito metodológico de melhor identificálas e classificá-las, pois não existe, nem mesmo entre os estudiosos da área, uma distinção definitiva entre ambas.

Na maioria dos trabalhos, utiliza-se apenas o termo analogia ou o termo metáfora para se referir a ambos os fenômenos. Noutras vezes, os dois termos aparecem, mas a diferença entre eles sequer é discutida ou são tomados como sinônimos. O que pode ser percebido em trechos como este, no qual os autores primeiro utilizam os dois termos, mas depois o reduzem 
a apenas um: "devemos ter cuidado com o uso de analogias e metáforas apresentadas nos livros didáticos, pois, em geral, não parece haver preocupação com a forma de abordagem dessas analogias nos livros" (ANDRADE; ZYLBERSZTAJN; FERRARI, 2000, p. 183) 5 .

Entre aqueles que arriscam uma distinção teórica, uma parte dos autores afirma que tanto a analogia quanto a metáfora são maneiras de se fazer comparações, mas a principal diferença entre elas é que a primeira faz isso parcialmente (alfa é como beta) enquanto a segunda faz de maneira total (alfa é beta). Entretanto, é fácil perceber a inconsistência dessas concepções em afirmações como a seguinte:

Em las metáforas hay una transferencia y se transfieren todos los significados de alfa hacia beta. En una metáfora decimos que "alfa es beta" (...). Enlaanalogíadecimos que "alfa es como beta", lacorrespondencia entre alfa y beta es sóloparcial,se restringe a algún aspecto (GODOY, 2002, p. 3).

Se todos os significados de alfa fossem transferidos à beta na metáfora, como propõe o autor, frases como "Julieta é o Sol" (William Shakespeare ${ }^{6}$ ) seriam simplesmente absurdas, já que pensaríamos Julieta como um astro de massa de $2 \times 10^{30} \mathrm{~kg}$ e temperatura de $6000 \mathrm{~K}$. O que compreendemos de imediato, com uma sentença como essa, é que Julieta possui apenas alguns aspectos atribuídos ao Sol (é radiante, é de extrema importância, é o centro do mundo para o seu amante, etc.). Logo, quando se diz que "Julieta é o Sol” (alfa é beta), se está dizendo que, na verdade, "Julieta é como o Sol" (alfa é como beta). A distinção proposta pelo autor é uma tentativa interessante, contudo, não se sustenta, pois, toda metáfora seria também uma analogia, mas nenhuma analogia seria uma metáfora.

A distinção pouco convincente apresentada por Godoy (2002), comum a outros autores, só mostra o quanto uma clara diferenciação entre os dois conceitos não é tão fácil.

Outra proposta de distinção, muito mais efetiva, é a de Duit (1991, p. 651), para quem

an analogy explicitly compares the structures of two domains; it indicates identity of parts of structures. A metaphor compares implicitly, highlighting features or relational qualities that do not coincide in two domains. Takenliterally, metaphors are plainly false (Grifos no original).

Nesse caso, a diferença não reside apenas na presença ou não do termo que evidencia a comparação (alfa é como beta/alfa é $\varnothing$ beta), nem no grau de transferência das características de um a outro (total ou parcial), mas nos domínios a que pertencem os termos compara-

\footnotetext{
${ }^{5}$ Isso se explica porque a base teórica deste artigo é o filósofo francês Gaston Bachelard, que em sua vasta obra também não estabeleceu distinção entre os dois conceitos.

${ }^{6}$ Romeu e Julieta, ato II, cena II.

7 Conforme se depreende de Duit (1991), domínio é o conjunto semântico e conceitual utilizado para explicar determinado fenômeno.
} 
dos. No caso da analogia, a aproximação entre duas coisas é dada por diferenças ou por semelhanças que existem ou poderiam existir, enquanto na metáfora são destacadas características entre domínios que não coincidem. Assim, uma frase como "podemos considerar as usinas nucleares semelhantes às usinas termelétricas, com exceção da fonte de energia primária, que nas usinas nucleares são reações nucleares e nas usinas termelétricas são reações químicas" (FIS 9, p. 236) é analógica, pois compara uma semelhança existente entre dois tipos de usinas. Já frases como "Segundo suas [de Newton] leis mecânicas, o Universo era uma vasta engrenagem" (FIS 3, p. 223) ou mesmo "o Universo era como uma engrenagem" só podem ser metáforas, uma vez que comparam o universo com a engrenagem de uma máquina (domínios muito distintos) e, se tomadas literalmente, são absurdas.

Mozzer e Justi (2015) chegam à mesma conclusão a partir da teoria de mapeamento de estrutura (structure-mapping). Para eles, "nas analogias existe uma identidade entre os elementos nos diferentes domínios e as relações entre eles são explicitamente mapeadas, nas metáforas a comparação é implícita e os atributos e relações não são coincidentes nos dois domínios" (p. 132. Grifos no original). Acrescentam, ainda, que se uma metáfora for explicitamente mapeada - o que a tornaria pedagogicamente mais eficiente para o ensino de ciências -, ela deixaria de ser compreendida como uma metáfora e passaria a ser entendida como uma analogia. Isso será discutido logo abaixo, no subcapítulo que trata das analogias e metáforas no ensino de Física.

Neste trabalho, a analogia é conceituada a partir da ideia de que ela aproxima duas coisas que já possuem semelhança entre si, e/ou pertencem ao mesmo domínio, para apresentar uma informação nova (alvo) a partir de uma informação já conhecida (veículo). Por exemplo: "o CRT [tubo de raios catódicos dos televisores antigos] acelera as partículas (elétrons) do cátodo e muda sua direção usando eletroímãs no vácuo. (...) Um acelerador de partículas funciona do mesmo modo (...)." (FIS 8, p. 264). Nesse trecho, aproximam-se dois objetos distintos (o tubo de raios catódicos dos televisores e o acelerador de partículas), mas que possuem características comuns (a de acelerar elétrons e mudar sua direção usando eletroímãs) e pertencem ao mesmo domínio.

Já a "metáfora, cria uma categoria que junta coisas que, no mundo real, estão bem separadas" (MOURA, 2012, p. 25). Por exemplo, em "havia outras nuvens escuras no céu azul da Física Clássica" (FIS 12, p. 248), cria-se uma categoria até então inexistente que estabelece uma relação entre "Física" e "céu".

Tanto na analogia quanto na metáfora existem duas coisas que são aproximadas ou comparadas. Uma delas é familiar e tem suas características - ao menos é o que o autor da figura de linguagem presume - já conhecidas. Para esta, é possível encontrar os nomes: conceito-análogo (ANDRADE; ZYLBERSZTAJN; FERRARI, 2000); veículo (vehicle) (CURTIS; REIGELUTH, 1984; SILVA; MARTINS, 2010; ROSA; CÓTICA; PEREIRA, 2016); campo fonte (PÁDUA, 2003); e - o mais comum - análogo (analog) (DUIT, 1991; THIELE; TREAGUST, 1994; OTERO, 1997; BOZELLI; NARDI, 2005; GONZÁLEZ, 2005; MOZ- 
ZER; JUSTI, 2015) ${ }^{8}$. A outra é uma informação nova, que terá suas características aproximadas da primeira. Para esta, os nomes mais comuns são: conceito-alvo (ANDRADE; ZYLBERSZTAJN; FERRARI, 2000); campo alvo (PÁDUA, 2003); branco (blanco) (OTERO, 1997); tópico (topic) (CURTIS; REIGELUTH, 1984; GONZÁLEZ, 2005), mas o mais comum mesmo é termo alvo (target) (DUIT, 1991; THIELE; TREAGUST, 1994; BOZELLI; NARDI, 2005; SILVA; MARTINS, 2010; ROSA; MOZZER; JUSTI, 2015; CÓTICA; PEREIRA, 2016) ${ }^{9}$.

Neste trabalho são utilizados os termos veículo e alvo. Assim, em aproximações como "vamos imaginar que o Universo seja um panetone" (FIS 2, p. 263), "o panetone” é o veículo, aquilo que já se conhece e é familiar; e "o universo", o alvo, a informação nova.

\section{III.2 Classificação das analogias e metáforas}

Como mencionado na justificativa, neste trabalho foi adotada uma classificação já existente para a classificação das analogias e metáforas encontradas em livros didáticos de Física. Essa classificação foi proposta por Curtis e Reigeluth (1984) e aplicada, modificada e aprimorada por diversos autores deste então.

\section{III.2.1 Relação (analogicalrelationship)}

Relação estrutural (structuralrelationship): são aproximadas as semelhanças físicas entre veículo e alvo.

Relação funcional (functionalrelationship): são aproximadas as funcionalidades entre veículo e alvo, aquilo que eles realizam.

Relação estrutural-funcional (structural-functionalrelationship): tanto as relações estruturais quanto funcionais são aproximadas.

\section{III.2.2 Formato de apresentação (presentationformat)}

Verbal (verbal): a analogia e/ou a metáfora é explicada apenas com palavras.

Pictórico-verbal (pictorial-verbal): a analogia e/ou a metáfora é reforçada com uso de uma imagem visual (fotografia, desenho etc.).

\section{III.2.3 Condição (condition)}

Concreto/concreto (concrete/concrete): o veículo e o alvo são de natureza concreta. Abstrato/abstrato (abstract/abstract): o veículo e o alvo são de natureza abstrata. Concreto/abstrato (concrete/abstract): o veículo é de natureza concreta e o alvo é de natureza abstrata.

\footnotetext{
8 Também se encontram os termos: foro, base ou fonte (source) e âncora (DUARTE, 2005).

9 Também se encontram os termos: objeto, problema, meta e tema (DUARTE, 2005).
} 
Abstrato/concreto (abstract/concrete): o veículo é de natureza abstrata e o alvo é de natureza concreta.

\section{III.2.4 Nível de enriquecimento (levelofenrichment)}

Simples (simple): a aproximação é feita apenas apresentando um veículo e um alvo.

Enriquecida (enriched): quando a aproximação entre veículo e alvo é explicada e os motivos para sua adoção deixados claros. Além disso, pode haver a presença de uma ou mais limitações para a validade da aproximação.

Estendida (extended): quando várias características dos veículos são usadas para aproximá-lo do alvo ou quando vários veículos são usados para explicar um mesmo alvo.

Silva e Martins (2010) definem da seguinte maneira os níveis enriquecido e expandido:

Enriquecida: Além do veículo e o alvo, trabalha ao menos uma relação (...). Estendida: Apresenta o veículo, o alvo, a relação, ou relações, entre eles, com ao menos uma limitação (SILVA; MARTINS, 2010, p. 268-269. Grifos no original).

Aqui foi mantida a definição original de Curtis e Reigeluth (1984).

\section{III.3 Analogias e metáforas nos livros didáticos de Física}

Os livros didáticos sempre tiveram grande peso econômico no mercado editorial e muitas das maiores editoras do país, hoje, mantêm-se graças a essas publicações. Para se ter uma ideia dessa importância, basta lembrar que, no Brasil, "os livros didáticos correspondiam, no início do século XX, a dois terços dos livros publicados e representavam, ainda em 1996, aproximadamente a 61\% da produção nacional” (CHOPPIN, 2004, p. 551). Número que aumentou ainda mais após 1996, com a aprovação da Lei de Diretrizes da Educação Nacional, e com a universalização do acesso ao livro didático. Em 2016 - mesmo após cortes no orçamento do MEC -, foram cerca de 130 milhões de exemplares adquiridos e distribuídos pelo Programa Nacional do Livro Didático, investimento que supera 1,2 bilhões de reais 10 .

Tais números acompanham o interesse pelas pesquisas na área. O livro didático começou a ganhar status de objeto científico no último meio século e a atenção por esse campo só vem crescendo. Internacionalmente, mais de $75 \%$ das publicações sobre o tema são posteriores a 1980 e mais de 50\% posteriores a 1990 (CHOPPIN, 2004). No Brasil, o crescimento no número de publicações se deu após 1996, com a promulgação da já referida LDB e do início do programa de avaliação contínua dos livros pelo MEC a partir do mesmo ano (LEITE; GARCIA; ROCHA, 2011).

\footnotetext{
${ }^{10}$ http://www.fnde.gov.br/programas/programas-do-livro/livro-didatico/dados-estatisticos
} 
As pesquisas sobre livros didáticos seguem duas grandes tendências. A primeira diz respeito à crítica ideológica e cultural dos livros, a segunda à análise epistemológica ou didática (CHOPPIN, 2004). Ainda que existam trabalhos que privilegiam a análise ideológica dos livros de Física, a imensa maioria das publicações se insere na segunda tendência. Isso porque há uma certa tradição em considerar que os livros de ciências exatas e naturais tenham uma função muito mais instrumental - na qual o livro didático se propõe a colocar em prática instrumentos de aprendizagem ou propor exercícios e resolução de problemas para adquirir competências e habilidades da área e/ou memorizar conteúdos (CHOPPIN, 2004, p. 553) - do que ideológica ou cultural. Ou seja, são considerados mais "neutros", ideologicamente falando, do que livros de outras áreas. Mesmo que isso seja uma falácia.

Dentre as pesquisas em livros didáticos de Física que fazem uma análise epistemológica ou didática, é possível dividir as abordagens em cinco categorias, em ordem de maior quantidade de trabalhos publicados (LEITE; GARCIA; ROCHA, 2011):

I) análise da linguagem empregada pelos autores;

II) análise dos conteúdos apresentados;

III) análise das metodologias de ensino adotadas;

IV) análise das relações dos livros com os sujeitos leitores (estudantes e professores);

V) análise da influência das políticas públicas sobre as publicações.

Já entre as investigações acerca da linguagem presente nos livros didáticos de Física, um ramo em especial trata do uso de analogias e/ou metáforas para explicar conceitos científicos ou aproximar o conhecimento prévio dos estudantes de conhecimentos novos a serem aprendidos. Esse campo de interesse merece tanta atenção que é citado como um critério eliminatório específico para o componente de Física na avaliação das coleções didáticas para o PNLD:

Para o componente curricular Física, foi observado se a obra, no Livro do Estudante: (...) utiliza analogias e metáforas de forma cuidadosa e adequada, garantindo a explicitação de suas semelhanças e diferenças em relação aos fenômenos/conceitos estudados, bem como de seus limites de validade (BRASIL, 2017b, p. 19-20).

Como se vê, o próprio MEC não condena o uso de analogias e metáforas nos livros didáticos, mas reconhece o emprego adequado dessas figuras de linguagem.

\section{III.4 Analogias e metáforas no Ensino de Física}

Analogias e metáforas possuem, cada uma a seu modo, possibilidades de uso didático no ensino de ciências em geral e de Física em específico. Várias são as publicações que atestam isso (CURTIS; REIGELUTH, 1984; DUIT, 1991; ANDRADE; ZYLBERSZTAJN; FERRARI, 2000; NAGEM; CARVALHAES; DIAS, 2001; PÁDUA, 2003; BOZELLI; NARDI, 2005; ANDRADE, 2014; MOZZER; JUSTI, 2015; ROSA; CÓTICA; PEREIRA, 2016), ressaltando tanto o caráter propositivo desse uso quanto o caráter restritivo. 
Dentre as vantagens didáticas, pode-se destacar que analogias e metáforas podem: aproximar conceitos familiares ou já estudados pelos estudantes (veículo) de conceitos novos (alvo);

apresentar conceitos abstratos, como é o caso da maioria dos conceitos científicos, de maneira concreta ou mais fácil de serem imaginados;

$>$ estimular o pensamento lógico;

$>$ exercitar a busca de padrões por meio de comparações entre semelhanças e diferenças;

desenvolver a criatividade e estimulam a imaginação;

permitir a percepção de concepções alternativas por parte dos estudantes;

tornar as aulas mais dinâmicas e estimulantes.

Dentre as desvantagens, aparece que as analogias e metáforas podem:

$>$ criar concepções alternativas ou obstáculos epistemológicos, quando não apresentadas as devidas limitações da aproximação entre veículo e alvo;

gerar dificuldades de compreensão, caso o veículo não seja tão familiar ao estudante quanto querem os autores do livro;

produzir generalizações que não podem ser feitas, quando o veículo e o alvo são muito semelhantes ou pertencem a campos da Física muito parecidos;

não permitir que os estudantes atinjam um grau de abstração necessário para a compreensão de determinado conceito científico.

Além dessas vantagens e desvantagens comuns às analogias e às metáforas, alguns autores destacam que a metáfora pode ser pedagogicamente menos efetiva do que a analogia, já que se abre para um maior número de interpretações e a aproximação entre veículo e alvo não é claramente estabelecida.

Assertivas metafóricas tais como "no modelo atômico de Bohr, átomos são sistemas solares" são bastante problemáticas no contexto da sala de aula, pois podem induzir a erros. $\mathrm{O}$ estudante pouco familiarizado com o veículo ou o alvo pode tomar a frase no sentido literal. Ou então, não conseguir identificar quais aspectos do veículo podem ser aproximados do alvo e quais não podem. Para minimizar esses erros, essa metáfora poderia ser mapeada da maneira mostrada no Quadro 1 (MOZZER; JUSTI, 2015).

Para os autores dessa proposta, ao se fazer esse mapeamento explicitamente, ela deixaria de ser uma metáfora e passaria a ser uma analogia, já que os domínios atômicos e planetários se tornariam domínios semelhantes e não mais distantes. De fato, esse mapeamento é muito útil para o uso da metáfora em sala de aula, mas nem sempre converte a metáfora em analogia, apenas em uma metáfora "dissecada". Entretanto, é importante trazer em destaque que as semelhanças entre os dois modelos, para além das dimensões dos dois sistemas, se encerram no tratamento dinâmico realizado pela mecânica clássica, uma vez que, de acordo com os postulados de Bohr, o equilíbrio dinâmico dos sistemas nos estados estacionários pode ser discutido com as considerações da mecânica ordinária, mas que as transições de energia entre 
esses estados envolvem emissões de radiação, cujas características devem ser tratadas segundo a teoria de Planck.

Quadro 1 - Mapeamento da aproximação entre o modelo atômico de Bohr e o sistema solar.

\begin{tabular}{|c|c|c|}
\hline $\begin{array}{c}\text { Alvo } \\
\text { (Modelo atômico de Bohr) }\end{array}$ & MAPEAMENTO & $\begin{array}{c}\text { ANÁLOGO } \\
\text { (Sistema solar) }\end{array}$ \\
\hline O elétron gira em torno do núcleo. & & Os planetas giram em torno do Sol. \\
\hline $\begin{array}{l}\text { O núcleo atrai os elétrons e é atraído } \\
\text { por ele. }\end{array}$ & & $\begin{array}{l}\text { O Sol atrai os planetas e é atraido } \\
\text { por eles. }\end{array}$ \\
\hline $\begin{array}{l}\text { O fato de o núcleo atrair os elétrons } \\
\text { faz com que os elétrons girem em } \\
\text { torno do núcleo. }\end{array}$ & & $\begin{array}{l}\text { O fato de o Sol atrair os planetas } \\
\text { faz com que os planetas girem em } \\
\text { torno do Sol. }\end{array}$ \\
\hline
\end{tabular}

Fonte: Mozzer; Justi, 2015, p. 129.

Para minimizar problemas como esse, existem algumas metodologias de ensino que privilegiam o uso de analogias e/ou metáforas. O mais difundido deles é modelo TWA (Teaching-with-Analogy) (GLYNN, 1991), que apresenta seis passos para o uso dessa figura de linguagem, também aplicável em metáforas:

1 - Introduzir o alvo;

2 - Perguntar aos estudantes o que eles lembram sobre o análogo (veículo);

3 - Identificar as características semelhantes entre alvo e análogo;

4 - Mapear as características semelhantes;

5 - Tirar conclusões;

6 - Apontar as limitações da comparação.

Aqui, não se pretende aprofundar esse assunto. Porém, as conclusões a que se chega neste trabalho podem ajudar na aplicação dessa e de outras metodologias baseadas em analogias e metáforas.

\section{Metodologia}

Foram analisados os capítulos referentes ao conteúdo de Física Moderna das doze (12) coleções didáticas de Física do ensino médio recomendados pelo Guia de Livros Didáticos - PNLD 2018 (BRASIL, 2017a). Além de apresentar os critérios de avaliação dos referidos livros, esse guia traz o catálogo contendo as opções possíveis de escolha para todas as escolas públicas de ensino médio do país. Após escolhidas, as coleções são adquiridas e distribuídas pelo MEC para serem usadas entre os anos de 2018 e 2020.

O passo inicial da pesquisa foi encontrar o estado da arte sobre as investigações acerca de analogias e metáforas em livros didáticos de Física a partir de publicações em periódi- 
cos científicos brasileiros e estrangeiros. Com base nesse estudo, foi possível a construção de um referencial teórico consistente. Também se chegou à metodologia de classificação de analogias criada por Curtis e Reigeluth (1984), largamente utilizada por pesquisadores da área, e a dados já publicados.

Após o estabelecimento de critérios, foi realizada a identificação, coleta e registro das analogias e metáforas presentes nos capítulos de Física Moderna. Para tanto, foi utilizado o método de análise de conteúdo proposto por Bardin (2002), por se tratar de um método que utiliza procedimentos sistemáticos que proporcionam o levantamento de indicadores que permitam a inferência de conhecimentos a partir de diversos conteúdos presentes, explicitamente ou não, em um texto. Conforme Bardin, a aplicação do método prevê três etapas essenciais: pré-análise, que é identificada como uma fase de escolha e organização dos textos; é um primeiro contato com os textos que serão analisados; exploração do material, que é o estudo e a identificação dos elementos presentes no texto que estão de acordo com o propósito do estudo e o tratamento dos resultados, que envolve a inferência e a interpretação. Ademais, os critérios de validade qualitativa, para formulação do corpus de pesquisa, são pautados pela exaustividade, que se refere ao esgotamento do texto abordado, ou seja, a realização de uma leitura minuciosa que pode ocorrer repetidas vezes; homogeneidade, que é a distinção clara entre os temas estudados; exclusividade, que garante a um mesmo elemento pertencer a uma única categoria; objetividade, refere-se à independência dos resultados em relação aos codificadores escolhidos, de modo que, para quaisquer codificadores os resultados serão os mesmos. E, por fim, adequação, que é o processo de adaptação aos objetivos do estudo (OLIVEIRA, 2008). A partir dessa análise, as ocorrências de analogias e metáforas foram classificadas dentro das categorias supracitadas por meio de quadros, tabelas e gráficos.

Por fim, os dados - tanto numéricos quanto os trechos em que as analogias e metáforas aparecem - são apresentados e discutidos.

\section{Apresentação e análise dos resultados}

As tabelas abaixo estão nomeadas de acordo com as nomenclaturas apresentadas neste trabalho. Nelas, é possível verificar o número de analogias e metáforas encontradas nos capítulos que tratam de conteúdos de Física Moderna das doze coleções didáticas aprovadas pelo PNLD 2018, bem como suas classificações.

Já no link a seguir, é possível consultar as tabelas contendo todas as ocorrências de analogias e metáforas registradas, bem como a página em que foram localizadas: $<$ http://hdl.handle.net/11624/2337>. Este material pode servir para consultas que embasem pesquisas futuras ou para a conferência dos resultados aqui apresentados ${ }^{11}$.

\footnotetext{
11 As páginas marcadas com um asterisco (*) dizem respeito às analogias usadas para se fazer distinções e não aproximações. Ver seção V.2.
} 
Tabela 2 - Analogias e metáforas em FIS 1.

\begin{tabular}{|c|c|c|c|}
\hline FIS 1 (51 pág.) & Classificação & $\begin{array}{c}\text { Analogias } \\
(5)\end{array}$ & $\begin{array}{c}\text { Metáforas } \\
\text { (4) }\end{array}$ \\
\hline \multirow[t]{3}{*}{ Relação } & Estrutural & 0 & 2 \\
\hline & Funcional & 2 & 2 \\
\hline & Estrutural-funcional & 3 & 0 \\
\hline \multirow{2}{*}{$\begin{array}{l}\text { Formato de apresen- } \\
\text { tação }\end{array}$} & Verbal & 3 & 3 \\
\hline & Pictórico-verbal & 2 & 1 \\
\hline \multirow[t]{4}{*}{ Condição } & Concreto/concreto & 2 & 1 \\
\hline & Abstrato/abstrato & 1 & 0 \\
\hline & Concreto/abstrato & 2 & 3 \\
\hline & Abstrato/concreto & 0 & 0 \\
\hline \multirow{3}{*}{$\begin{array}{l}\text { Nível de enriqueci- } \\
\text { mento }\end{array}$} & Simples & 0 & 2 \\
\hline & Enriquecida & 2 & 2 \\
\hline & Estendida & 3 & 0 \\
\hline
\end{tabular}

Tabela 3 - Analogias e metáforas em FIS 2.

\begin{tabular}{|c|c|c|c|}
\hline FIS 2 (39 pág.) & Classificação & $\begin{array}{c}\text { Analogias } \\
\text { (5) }\end{array}$ & $\begin{array}{c}\text { Metáforas } \\
\text { (5) }\end{array}$ \\
\hline \multirow[t]{3}{*}{ Relação } & Estrutural & 0 & 5 \\
\hline & Funcional & 2 & 0 \\
\hline & Estrutural-funcional & 3 & 0 \\
\hline \multirow{2}{*}{$\begin{array}{l}\text { Formato de apresen- } \\
\text { tação }\end{array}$} & Verbal & 4 & 3 \\
\hline & Pictórico-verbal & 1 & 2 \\
\hline \multirow[t]{4}{*}{ Condição } & Concreto/concreto & 1 & 0 \\
\hline & Abstrato/abstrato & 3 & 0 \\
\hline & Concreto/abstrato & 1 & 5 \\
\hline & Abstrato/concreto & 0 & 0 \\
\hline \multirow{3}{*}{$\begin{array}{l}\text { Nível de enriqueci- } \\
\text { mento }\end{array}$} & Simples & 0 & 2 \\
\hline & Enriquecida & 2 & 3 \\
\hline & Estendida & 3 & 0 \\
\hline
\end{tabular}


Tabela 4 - Analogias e metáforas em FIS 3.

\begin{tabular}{|c|c|c|c|}
\hline FIS 3 (58 pág.) & Classificação & $\begin{array}{c}\text { Analogias } \\
(7)\end{array}$ & $\begin{array}{c}\text { Metáforas } \\
\text { (4) }\end{array}$ \\
\hline \multirow[t]{3}{*}{ Relação } & Estrutural & 0 & 3 \\
\hline & Funcional & 3 & 1 \\
\hline & Estrutural-funcional & 4 & 0 \\
\hline \multirow{2}{*}{$\begin{array}{l}\text { Formato de apresen- } \\
\text { tação }\end{array}$} & Verbal & 4 & 4 \\
\hline & Pictórico-verbal & 3 & 0 \\
\hline \multirow[t]{4}{*}{ Condição } & Concreto/concreto & 4 & 0 \\
\hline & Abstrato/abstrato & 3 & 0 \\
\hline & Concreto/abstrato & 0 & 4 \\
\hline & Abstrato/concreto & 0 & 0 \\
\hline \multirow{3}{*}{$\begin{array}{l}\text { Nível de enriqueci- } \\
\text { mento }\end{array}$} & Simples & 0 & 3 \\
\hline & Enriquecida & 2 & 1 \\
\hline & Estendida & 5 & 0 \\
\hline
\end{tabular}

Tabela 5 - Analogias e metáforas em FIS 4.

\begin{tabular}{llcc}
\hline FIS 4 (67 pág.) & Classificação & $\begin{array}{c}\text { Analogias } \\
(\mathbf{1 1})\end{array}$ & $\begin{array}{c}\text { Metáforas } \\
\mathbf{( 1 3 )}\end{array}$ \\
\hline \multirow{2}{*}{ Relação } & Estrutural & 1 & 6 \\
\cline { 2 - 4 } & Funcional & 6 & 7 \\
\cline { 2 - 4 } & Estrutural-funcional & 4 & 0 \\
\hline \multirow{2}{*}{$\begin{array}{l}\text { Formato de apresen- } \\
\text { tação }\end{array}$} & Verbal & 5 & 10 \\
\cline { 2 - 4 } Condição & Pictórico-verbal & 6 & 3 \\
& Concreto/concreto & 4 & 1 \\
\cline { 2 - 4 } & Abstrato/abstrato & 2 & 0 \\
\cline { 2 - 4 } & Concreto/abstrato & 5 & 12 \\
\cline { 2 - 4 } & Abstrato/concreto & 0 & 0 \\
\hline mível de enriqueci- & Simples & 1 & 5 \\
\cline { 2 - 4 } mento & Enriquecida & 2 & 1 \\
\cline { 2 - 4 } & Estendida & & 7 \\
\hline
\end{tabular}


Tabela 6 - Analogias e metáforas em FIS 5.

\begin{tabular}{llcc}
\hline FIS 5 (31 pág.) & Classificação & $\begin{array}{c}\text { Analogias } \\
\text { (2) }\end{array}$ & $\begin{array}{c}\text { Metáforas } \\
\text { (3) }\end{array}$ \\
\hline \multirow{2}{*}{ Relação } & Estrutural & 0 & 2 \\
\cline { 2 - 4 } & Funcional & 1 & 1 \\
\cline { 2 - 4 } & Estrutural-funcional & 1 & 0 \\
\hline \multirow{2}{*}{$\begin{array}{l}\text { Formato de apresen- } \\
\text { tação }\end{array}$} & Verbal & 1 & 2 \\
\cline { 2 - 4 } Condição & Pictórico-verbal & 1 & 1 \\
\cline { 2 - 4 } & Concreto/concreto & 1 & 0 \\
\cline { 2 - 4 } & Abstrato/abstrato & 1 & 1 \\
\cline { 2 - 4 } mento & Concreto/abstrato & 0 & 2 \\
\cline { 2 - 4 } & Abstrato/concreto & 0 & 0 \\
\hline
\end{tabular}

Tabela 7 - Analogias e metáforas em FIS 6.

\begin{tabular}{llcc}
\hline FIS 6 (94 pág.) & Classificação & $\begin{array}{c}\text { Analogias } \\
\mathbf{( 1 3 )}\end{array}$ & $\begin{array}{c}\text { Metáforas } \\
\mathbf{( 8 )}\end{array}$ \\
\hline \multirow{2}{*}{ Relação } & Estrutural & 2 & 6 \\
\cline { 2 - 4 } & Funcional & 6 & 2 \\
\cline { 2 - 4 } & Estrutural-funcional & 5 & 0 \\
\hline \multirow{2}{*}{$\begin{array}{l}\text { Formato de apresen- } \\
\text { tação }\end{array}$} & Verbal & 6 & 7 \\
\cline { 2 - 4 } Condição & Pictórico-verbal & 7 & 1 \\
\cline { 2 - 4 } & Concreto/concreto & 9 & 2 \\
\cline { 2 - 4 } & Abstrato/abstrato & 4 & 0 \\
\cline { 2 - 4 } mento & Concreto/abstrato & 0 & 6 \\
\cline { 2 - 4 } & Abstrato/concreto & 0 & 0 \\
\hline
\end{tabular}


Tabela 8 - Analogias e metáforas em FIS 7.

\begin{tabular}{llcc}
\hline FIS 7 (29 págs) & Classificação & $\begin{array}{c}\text { Analogias } \\
(\mathbf{8})\end{array}$ & $\begin{array}{c}\text { Metáforas } \\
(\mathbf{0})\end{array}$ \\
\hline \multirow{2}{*}{ Relação } & Estrutural & 0 & 0 \\
\cline { 2 - 4 } & Funcional & 3 & 0 \\
\cline { 2 - 4 } & Estrutural-funcional & 5 & 0 \\
\hline \multirow{2}{*}{$\begin{array}{l}\text { Formato de apresen- } \\
\text { tação }\end{array}$} & Verbal & 3 & 0 \\
\cline { 2 - 4 } Condição & Pictórico-verbal & 5 & 0 \\
\cline { 2 - 4 } & Concreto/concreto & 4 & 0 \\
\cline { 2 - 4 } & Abstrato/abstrato & 4 & 0 \\
\cline { 2 - 4 } mento & Concreto/abstrato & 0 & 0 \\
\cline { 2 - 4 } & Abstrato/concreto & 0 & 0 \\
\hline
\end{tabular}

Tabela 9 - Analogias e metáforas em FIS 8.

\begin{tabular}{llcc}
\hline FIS 8 (42 págs) & Classificação & $\begin{array}{c}\text { Analogias } \\
\mathbf{( 7 )}\end{array}$ & $\begin{array}{c}\text { Metáforas } \\
\text { (6) }\end{array}$ \\
\hline \multirow{2}{*}{ Relação } & Estrutural & 0 & 2 \\
\cline { 2 - 4 } & Funcional & 2 & 3 \\
\cline { 2 - 4 } & Estrutural-funcional & 5 & 1 \\
\hline \multirow{2}{*}{$\begin{array}{l}\text { Formato de apresen- } \\
\text { tação }\end{array}$} & Verbal & 2 & 3 \\
\cline { 2 - 4 } Condição & Pictórico-verbal & 5 & 3 \\
\cline { 2 - 4 } & Concreto/concreto & 4 & 2 \\
\cline { 2 - 4 } & Abstrato/abstrato & 2 & 0 \\
\hline Nível de & Concreto/abstrato & 1 & 4 \\
\cline { 2 - 4 } mento & Abstrato/concreto & 0 & 0 \\
\hline & Simples & 0 & 4 \\
\cline { 2 - 4 } & Enriquecida & 4 & 1 \\
\cline { 2 - 4 } & Estendida & & 4 \\
\hline
\end{tabular}


Tabela 10 - Analogias e metáforas em FIS 9.

\begin{tabular}{|c|c|c|c|}
\hline FIS 9 (106 pág.) & Classificação & $\begin{array}{c}\text { Analogias } \\
(9)\end{array}$ & $\begin{array}{c}\text { Metáforas } \\
\text { (5) }\end{array}$ \\
\hline \multirow[t]{3}{*}{ Relação } & Estrutural & 0 & 1 \\
\hline & Funcional & 3 & 3 \\
\hline & Estrutural-funcional & 6 & 1 \\
\hline \multirow{2}{*}{$\begin{array}{l}\text { Formato de apresen- } \\
\text { tação }\end{array}$} & Verbal & 3 & 5 \\
\hline & Pictórico-verbal & 6 & 0 \\
\hline \multirow[t]{4}{*}{ Condição } & Concreto/concreto & 6 & 0 \\
\hline & Abstrato/abstrato & 3 & 0 \\
\hline & Concreto/abstrato & 0 & 4 \\
\hline & Abstrato/concreto & 0 & 1 \\
\hline \multirow{3}{*}{$\begin{array}{l}\text { Nível de enriqueci- } \\
\text { mento }\end{array}$} & Simples & 0 & 1 \\
\hline & Enriquecida & 5 & 3 \\
\hline & Estendida & 4 & 1 \\
\hline
\end{tabular}

Tabela 11 - Analogias e metáforas em FIS 10.

\begin{tabular}{|c|c|c|c|}
\hline FIS 10 (72 pág.) & Classificação & $\begin{array}{c}\text { Analogias } \\
(7)\end{array}$ & $\begin{array}{c}\text { Metáforas } \\
\text { (8) }\end{array}$ \\
\hline \multirow[t]{3}{*}{ Relação } & Estrutural & 0 & 7 \\
\hline & Funcional & 3 & 1 \\
\hline & Estrutural-funcional & 4 & 0 \\
\hline \multirow{2}{*}{$\begin{array}{l}\text { Formato de apresen- } \\
\text { tação }\end{array}$} & Verbal & 4 & 7 \\
\hline & Pictórico-verbal & 3 & 1 \\
\hline \multirow[t]{4}{*}{ Condição } & Concreto/concreto & 2 & 1 \\
\hline & Abstrato/abstrato & 4 & 0 \\
\hline & Concreto/abstrato & 1 & 7 \\
\hline & Abstrato/concreto & 0 & 0 \\
\hline \multirow{3}{*}{$\begin{array}{l}\text { Nível de enriqueci- } \\
\text { mento }\end{array}$} & Simples & 0 & 5 \\
\hline & Enriquecida & 1 & 2 \\
\hline & Estendida & 6 & 1 \\
\hline
\end{tabular}


Tabela 12 - Analogias e metáforas em FIS 11.

\begin{tabular}{|c|c|c|c|}
\hline FIS 11 (69 pág.) & Classificação & $\begin{array}{c}\text { Analogias } \\
(6)\end{array}$ & $\begin{array}{c}\text { Metáforas } \\
\text { (5) }\end{array}$ \\
\hline \multirow[t]{3}{*}{ Relação } & Estrutural & 0 & 4 \\
\hline & Funcional & 1 & 1 \\
\hline & Estrutural-funcional & 5 & 0 \\
\hline \multirow{2}{*}{$\begin{array}{l}\text { Formato de apresen- } \\
\text { tação }\end{array}$} & Verbal & 2 & 4 \\
\hline & Pictórico-verbal & 4 & 1 \\
\hline \multirow[t]{4}{*}{ Condição } & Concreto/concreto & 2 & 1 \\
\hline & Abstrato/abstrato & 3 & 0 \\
\hline & Concreto/abstrato & 1 & 4 \\
\hline & Abstrato/concreto & 0 & 0 \\
\hline \multirow{3}{*}{$\begin{array}{l}\text { Nível de enriqueci- } \\
\text { mento }\end{array}$} & Simples & 0 & 4 \\
\hline & Enriquecida & 2 & 1 \\
\hline & Estendida & 4 & 0 \\
\hline
\end{tabular}

Tabela 13 - Analogias e metáforas em FIS 12.

\begin{tabular}{llcc}
\hline FIS 12 (52 pág.) & Classificação & $\begin{array}{c}\text { Analogias } \\
\text { (4) }\end{array}$ & $\begin{array}{c}\text { Metáforas } \\
\text { (6) }\end{array}$ \\
\hline \multirow{2}{*}{ Relação } & Estrutural & 0 & 6 \\
\cline { 2 - 4 } & Funcional & 2 & 0 \\
\cline { 2 - 4 } & Estrutural-funcional & 2 & 0 \\
\hline \multirow{2}{*}{$\begin{array}{l}\text { Formato de apresen- } \\
\text { tação }\end{array}$} & Verbal & 2 & 5 \\
\cline { 2 - 4 } Condição & Pictórico-verbal & 2 & 1 \\
& Concreto/concreto & 2 & 3 \\
\cline { 2 - 4 } & Abstrato/abstrato & 1 & 0 \\
\cline { 2 - 4 } & Concreto/abstrato & 1 & 3 \\
\cline { 2 - 4 } $\begin{array}{l}\text { Nível de } \\
\text { mento }\end{array}$ & Abstrato/concreto & 0 & 0 \\
& Simples & 1 & 4 \\
\cline { 2 - 4 } & Enriquecida & 3 & 0 \\
\cline { 2 - 4 } & Estendida & & 2 \\
\hline
\end{tabular}

\section{1 Analogias}

O maior número de analogias, presente em todos os livros analisados, diz respeito à comparação dos fenômenos sob a perspectiva da Física Clássica (veículo) com os fenômenos sob a perspectiva da Física Moderna, Relativística ou Quântica (alvo). Isso é bastante espera- 
do, uma vez que essas áreas propõem explicações que costumam estar distantes dos fenômenos observáveis na realidade do estudante. Isso também ocorre porque, em geral, são os capítulos finais dos cursos de Física no ensino médio e se supõe que os conhecimentos de Física Clássica já sejam familiares ao aluno.

Em todos os livros em que aparece, essa analogia é estendida, já que a aproximação é feita comparando-se várias características do veículo por um ou mais capítulos inteiros. Um exemplo é quando se comparam efeitos de deslocamento a baixas velocidades - conhecimento familiar e intuitivo - com efeitos de deslocamento à velocidades próximas à da luz. Ou, como a seguir, em que se compara o efeito Doppler já estudado pelo discente com o novo conhecimento introduzido pelos efeitos relativísticos:

Como já vimos no estudo do movimento ondulatório, se uma fonte de ondas e um observador têm algum tipo de movimento relativo entre si, as ondas emitidas pela fonte são captadas pelo observador com uma frequência alterada, sendo ela maior na aproximação e menor no afastamento entre ambos. Esse fenômeno é conhecido como efeito Doppler-Fizeau e ocorre com ondas tanto mecânicas quanto eletromagnéticas.

Entretanto, para as ondas eletromagnéticas, não se aplicam as equações da frequência e do comprimento de onda aparentes, deduzidas para as ondas mecânicas.

A expressão correta para o efeito Doppler longitudinal eletromagnético ou efeito Doppler relativístico é:

$$
f^{\prime}=f_{0} \cdot \sqrt{\frac{c \pm v}{c \mp v}}
$$

(FIS 10, p. 195).

No caso da aproximação entre Física Clássica e Física Quântica, temos exemplos como este:

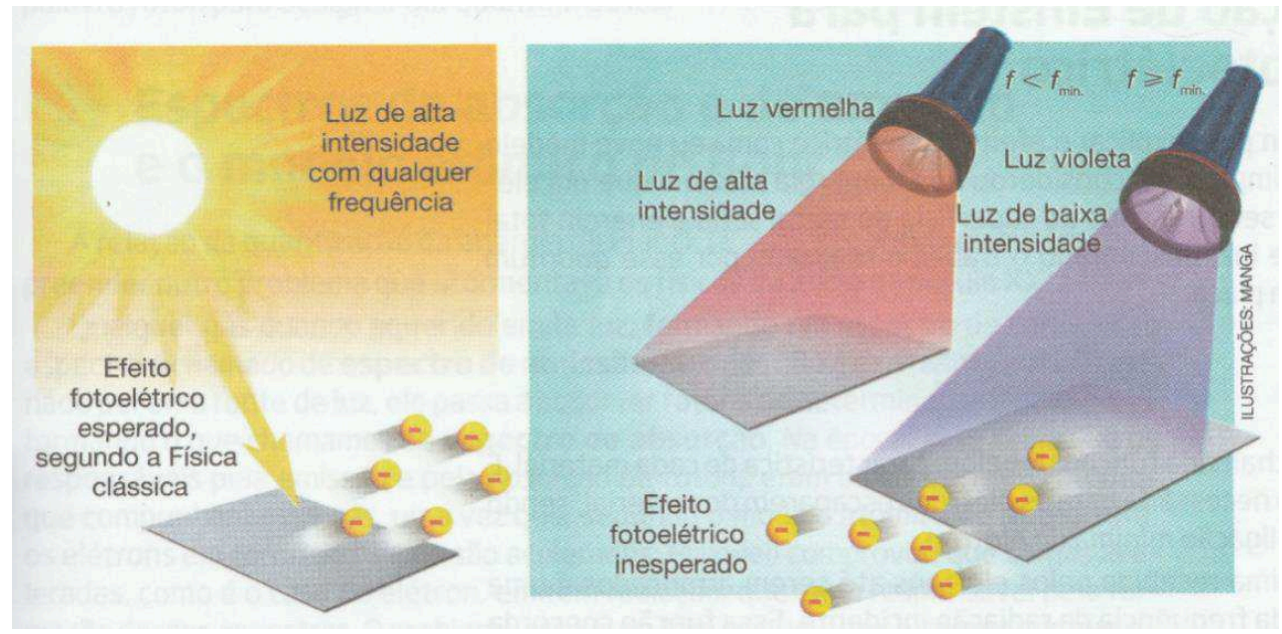

(FIS 8, p. 245)

Nessa imagem, o efeito fotoelétrico é comparado entre aquele esperado pela Física Clássica e aquele que é explicado pela Física Quântica. 


\section{2 Contra-analogias}

Aqui, vale fazer uma observação muito importante acerca de um resultado que emergiu dos dados coletados. Muitos autores consideram analogias e metáforas como comparações em que as semelhanças são privilegiadas. Contudo, percebeu-se que é bastante comum, como pode ser visto acima, o uso de analogias também para se fazer distinções. Isso não apareceu mencionado em nenhum trabalho pesquisado. Ferry e Nagem (2008) apresentam um conceito - ao que tudo indica, criado por eles - que poderia se encaixar com essa premissa, o de contra-analogia:

partindo da definição adotada para o conceito de analogia, que a considera como uma comparação baseada em similaridades entre estruturas de dois domínios diferentes, uma contra-analogia deverá ser entendida também como uma comparação entre estruturas de domínios distintos, que se baseia, porém, nas diferenças (FERRY; NAGEM, 2008, p. 16. Grifo no original).

Todavia, os autores não especificam como se daria a construção dessas contraanalogias. O único exemplo presente no artigo - que diz que "o átomo, de acordo com a teoria de Thomson, não seria como um doce brigadeiro" (sic) (FERRY; NAGEM, 2008, p. 16. Grifo no original), em contraposição ao do famoso "pudim de passas" (ver adiante) - além de não ter sido extraído de uma ocorrência real, não esclarece suas propostas, como bem aponta Mozzer e Justi (2015, p. 126):

não ficam claras na proposição [da contra-analogia] quais seriam as vantagens dessa comparação para a aprendizagem dos estudantes, uma vez que tal constructo não se baseia na premissa fundamental das analogias, a saber, a de favorecer a compreensão do não familiar a partir do familiar pela combinação entre o estabelecimento das relações de similaridade e o reconhecimento das diferenças.

O que talvez nem Ferry e Nagem (2008) nem Mozzer e Justi (2015) perceberam é que esse tipo de ocorrência é comum e abundante nas coleções didáticas analisadas. Foram encontrados 49 casos do tipo, principalmente com analogias (46), mas também com metáforas (3) como em: "Não imagine a quebra do urânio como um impacto do nêutron, como acontece com uma vidraça sendo espatifada por uma pedra (FIS 9, p. 235) ou "Estudos posteriores mostraram que o núcleo atômico não é uma 'bolinha' rígida, como foi imaginado de início" (FIS 10, p. 233). O livro FIS 7 é um caso curioso, pois 100\% das ocorrências encontradas são analogias que destacam as diferenças ao invés das semelhanças.

A efetividade desses usos, como as que aproximam os fenômenos sob a perspectiva da Física Clássica dos fenômenos sob a perspectiva da Física Moderna, bem como das analogias e metáforas que privilegiam as distinções, precisam ser estudados em situações concretas de ensino para conclusões quanto a sua eficiência. Porém, parecem ser bons recursos quando empregados nos livros didáticos, já que permitem contrastar conhecimentos familiares ou já 
estudados com outros conhecimentos pouco intuitivos ou distantes da realidade imediata do estudante.

\section{3 Metáforas}

Nos casos das metáforas, uma recorrência é a que usa desse recurso para explicar modelos atômicos, como a que aproxima o sistema solar do modelo proposto por Rutherford ou por Nagaoka (FIS 2, 4, 5, 6 e 10). A aproximação entre o modelo de Thomson e o "pudim de passas" (ou ameixa) foi a que mais apareceu (FIS 1, 4, 6, 8, 11 e 12). Em apenas um caso a aproximação foi feita com uma melancia: “(...) Thomson (1856-1940) sugeriu um modelo no qual os elétrons com cargas negativas estariam distribuídos uniformemente em um grande volume de carga positiva, mais ou menos como as sementes em uma melancia" (FIS 10, p. 214). Isso aparece representado tanto apenas por palavras quanto também por figuras.

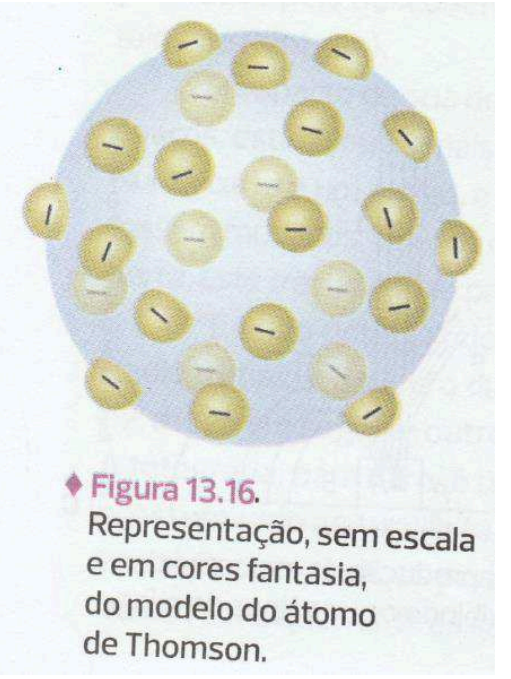

A distribuição das "passas" negativas seria simétrica em uma massa positiva uniforma. (FIS 4, p. 244).

Outra metáfora que aparece em alguns dos livros é a que aproxima a expansão do universo (alvo) à massa de um panetone levado ao forno (FIS 2) ou à um balão sendo inflado (FIS 6 e 11) (veículos). Nessas ocorrências, a metáfora é enriquecida, pois foi explicada e os motivos para sua adoção foram deixados claros. No caso de FIS 11 (p. 269), até mesmo se sugere um experimento com um balão para que o estudante possa compreender a metáfora.

O mesmo não acontece com a metáfora dos "pequenos pacotes" para os quanta de energia (FIS 1, 3, 4, 6, 10, 11 e 12) ou da "fornalha" para as estrelas (FIS 6, 10 e 11), que são simples em todas as ocorrências. É necessário investigar os efeitos dessas metáforas na aprendizagem real, mas fica evidente que elas são empregadas por tradição e carecem de um cuidado maior por parte dos autores. Em oposição a esses usos pouco desenvolvidos, pode-se tomar como exemplo a aproximação entre os degraus de uma escada (veículo) e os estados estacio- 
nários de um átomo (alvo), do livro FIS 2, no qual é possível apreender como os autores utilizaram do tradicional emprego da metáfora estrutural "salto quântico" para criar uma metáfora pedagogicamente relevante para explicar esse conceito abstrato, assim como feito com o balão mencionado acima:

Os estados estacionários (níveis permitidos de energia) de um átomo, citados anteriormente, podem ser comparados aos degraus de uma escada. Essa comparação só não é perfeita porque as diferenças de energia entre os diversos estados possíveis são bastante irregulares.

No caso de uma radiação eletromagnética incidir em um átomo, um elétron dele só pode absorver um fóton (quantum de energia) se a energia deste (hf) for exatamente a quantidade de energia necessária para o elétron "saltar" de um nível permitido para outro também permitido. Caso contrário, ele não o absorve.

Observe, na figura a seguir, um elétron que absorve um fóton e salta do estado fundamental, de energia $\mathbf{E}_{1}$, para o estado excitado, de energia $\mathbf{E}_{4}$.

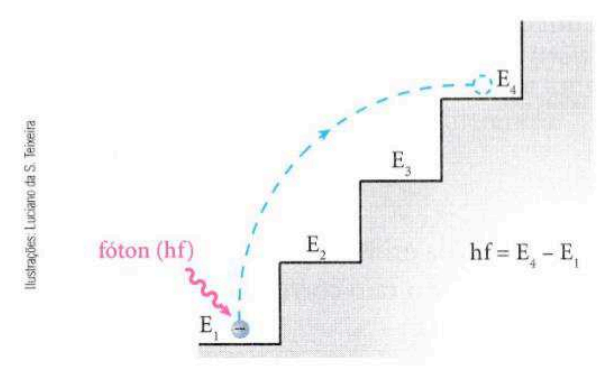

(FIS, 2, p. 260)

O maior problema identificado foi que praticamente não há, por parte dos autores, um cuidado quanto a se deixar explícito ao estudante quando se está utilizando uma metáfora. A única marca, nesse sentido, é quando aparecem aspas (") para destacar que um termo não está sendo tomado em seu sentido literal. Isso, contudo, nem sempre pode ser suficiente, cabendo ao professor que utiliza o livro fazer essa explicitação e também apontar os limites da aproximação.

\section{4 Comparação entre analogias e metáforas encontradas}

$\mathrm{Na}$ tabela a seguir, estão catalogadas todas as ocorrências de analogias e metáforas encontradas nas doze coleções didáticas. Foram encontradas um total de 84 analogias e 67 metáforas em 710 páginas. 
Tabela 14 - Analogias e metáforas em todas as coleções analisadas.

\begin{tabular}{llcc}
\hline TOTAL (710 pág.) & Classificação & $\begin{array}{c}\text { Analogias } \\
(\mathbf{8 4 )}\end{array}$ & $\begin{array}{c}\text { Metáforas } \\
\mathbf{( 6 7 )}\end{array}$ \\
\hline \multirow{2}{*}{ Relação } & Estrutural & 3 & 44 \\
\cline { 2 - 4 } & Funcional & 34 & 21 \\
\cline { 2 - 4 } & Estrutural-funcional & 47 & 2 \\
\hline \multirow{2}{*}{$\begin{array}{l}\text { Formato de apresen- } \\
\text { tação }\end{array}$} & Verbal & 39 & 53 \\
\cline { 2 - 4 } Condição & Pictórico-verbal & 45 & 14 \\
& Concreto/concreto & 41 & 11 \\
\cline { 2 - 4 } & Abstrato/abstrato & 31 & 1 \\
\cline { 2 - 4 } & Concreto/abstrato & 12 & 54 \\
\cline { 2 - 4 } & Abstrato/concreto & 0 & 1 \\
\hline mível de enriqueci- & Simples & 32 & 26 \\
\cline { 2 - 4 } mento & Enriquecida & 50 & 4 \\
\cline { 2 - 4 } & Estendida & & 37 \\
\hline
\end{tabular}

Como é possível perceber, quase não há analogias estruturais $(3,57 \%)$, enquanto que a maioria das metáforas $(65,67 \%)$ estabelece essa relação. Simetricamente em oposição, a maioria das analogias estabelece uma relação do tipo estrutural-funcional (55,95\%), enquanto quase nenhuma metáfora $(2,99 \%)$ o faz. Isso é coerente com a concepção teórica aqui adotada, uma vez que, por aproximarem coisas que pertencem a um mesmo domínio, veículo e alvo tendem a ter mais características em comum (semelhança física e função) nas analogias. Já as metáforas até podem fazer essa aproximação em relação a suas funções, mas seu papel principal parece ser o de aproximar em relação às semelhanças físicas, como é o caso do pudim de passas para o modelo atômico de Rutherford ou do balão para a expansão do universo.

Quanto ao formato de apresentação, é esperado que as metáforas sejam mais verbais $(79,10 \%)$ do que pictórico-verbais $(20,90 \%)$, já que a aproximação criada, entre domínios muito diferentes, nem sempre pode ser representada por um desenho ou foto. Quando aparecem, como é o caso da escada para os estados estacionários do átomo (visto acima), geralmente são bem desenvolvidas e seus limites apresentados. Isso evidencia o cuidado dos autores das coleções em se adequar aos critérios de avaliação do PNLD. Os únicos três casos em que as metáforas pictórico-verbais não foram explicitadas apareceram em FIS 5, 8 e 10, ao representarem os já clássicos modelos atômicos de Thomson e Rutherford como um pudim de passas e o sistema solar, respectivamente. Seria preciso um cuidado maior para evitar que o estudante tome a imagem como a coisa mesma.

Outra assimetria entre analogia e metáfora é dada pela condição que estabelecem na aproximação. $\mathrm{Na}$ analogia, em $85,71 \%$ dos casos tanto o veículo quanto o alvo são ambos concretos $(48,81 \%)$ ou ambos abstratos $(36,90 \%)$, o que se justifica, pois em geral pertencem 
ao mesmo domínio. Nos casos em que isso não ocorre $(14,29 \%)$, a natureza concreta do veículo se dá pela proximidade com a realidade do estudante, enquanto o caráter abstrato do alvo se dá pela sua distância conceitual, como quanto se aproxima a determinação da velocidade e da posição de objetos macroscópicos (veículo - concreto) com a ideia do princípio de incerteza (alvo - abstrato).

Já a metáfora, pelo contrário, tem um propósito claro de aproximar domínios distintos, por isso a grande maioria $(82,09 \%)$ aproxima domínios em condições opostas (concreto/abstrato ou abstrato/concreto). As raras exceções têm potencial pedagógico pequeno, como a que aproxima fornalha (veículo) de estrelas (alvo).

É curioso destacar que a única ocorrência de uma aproximação do tipo abstrato/concreto foi com uma metáfora que brincou com o maniqueísmo bem x mal, aproximando a ideia de anjos e demônios (veículos) dos usos positivos e negativos da energia nuclear (alvo) no livro FIS 9 (p. 243).

Como pode ser observado nos gráficos seguintes, a dissimetria entre analogia e metáfora se repete também no caso do nível de enriquecimento.

Gráfico 1 - Nível de enriquecimento das analogias.

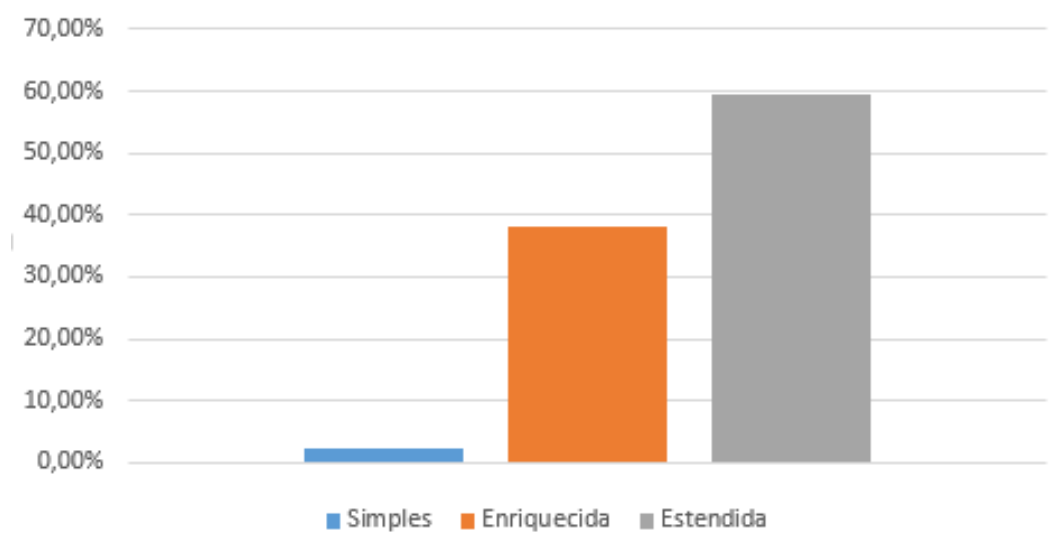

Fonte: Elaborada pelos autores.

Fica bastante evidente que as analogias são mais desenvolvidas que as metáforas. Porque aproximam coisas que pertencem ao mesmo domínio, elas têm maior possibilidade de que várias características do veículo sejam aproximadas do alvo, o que é muito difícil de ocorrer com as metáforas, que buscam aproximar domínios muito distantes. Mesmo assim, em ambos os casos, percebe-se o esforço dos autores em tentar explicar os motivos da aproximação (enriquecidas), conforme os critérios estabelecidos pela avaliação do PNLD. Quanto ao grande número de metáforas simples, esse dado mostra a importância de o professor saber identificá-las e explicitá-las aos estudantes, já que os livros nem sempre cumprem esse papel. 
Gráfico 2 - Nível de enriquecimento das metáforas.

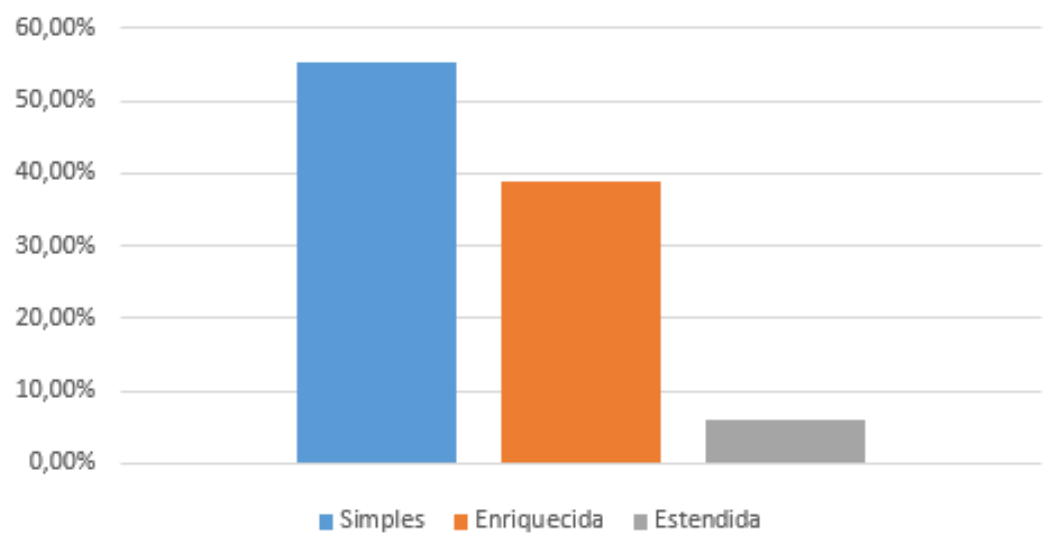

Fonte: Elaborada pelos autores.

\section{Considerações finais}

Neste trabalho, se analisaram as ocorrências de analogias e metáforas presentes em capítulos de Física Moderna nas coleções didáticas aprovadas pelo MEC e indicadas pelo Guia de Livros Didáticos - PNLD 2018. Essas ocorrências foram rigorosamente catalogadas e classificadas. Os dados qualitativos mostram que tanto as analogias quanto as metáforas são utilizadas quando os autores pretendem aproximar informações familiares ou conhecimentos já estudados pelo discente de informações novas. No ensino de Física, isso é importante, uma vez que os conceitos científicos estão distanciados dos saberes com que o estudante chega à escola e esses recursos podem ser uma ferramenta didática valiosa. No caso do ensino de Física Moderna, em particular, as ocorrências registradas apontam que essas figuras de linguagem são largamente utilizadas, em especial na aproximação entre os conceitos da Física Clássica e os conceitos da Física Relativística e Quântica. Além disso, um resultado inesperado - que não é mencionado em nenhum outro trabalho que analisa livros didáticos - apontou que as analogias e metáforas não são usadas apenas na comparação de semelhanças, mas também de diferenças entre conceitos, o que pode torna-las ferramentas didáticas ainda mais interessantes.

Quanto aos dados numéricos que emergiram da pesquisa, pode-se destacar a sua coerência em demonstrar as previsões teóricas: de que existe uma assimetria entre as características das analogias e das metáforas em uso nos livros didáticos. Enquanto a primeira busca aproximar coisas que pertencem a um mesmo domínio e - por isso, guarda um maior número de características que podem ser comparadas -, as metáforas aproximam coisas que pertencem a domínios muito distintos, criando um vínculo imaginário entre eles. Em termos pedagógicos, o conhecimento dessa diferença é relevante para as possíveis aplicações dessas figuras no ensino de Física.

Das dificuldades encontradas, pode-se destacar a falta de critérios precisos, baseados 
em pesquisas linguísticas atuais, para embasar a teoria das figuras de linguagem nas ciências. Muitos artigos só consideram analogias e metáforas quando essas vêm marcadas por termos que evidenciam a comparação, mas negligenciam o fato de que a aproximação entre diferentes coisas pode ser feita com ou sem esses termos, já que o uso real da linguagem é dinâmico, imprevisível e criativo.

Da mesma maneira, a inexistência de corpus de pesquisa que permitam a verificação e análise dos dados encontrados por estudos já realizados é um empecilho para os avanços na área. O ideal seria a criação de um banco de dados compartilhado em que seriam registradas e discutidas as ocorrências de analogias, metáforas e outras figuras de linguagem em livros didáticos por diversos pesquisadores. Ainda que os livros didáticos tenham validade de três anos, a maior parte dos textos entre uma edição e outra permanece o mesmo, o que garantiria a perenidade dos registros. Um banco de dados também seria imprescindível para a criação de uma classificação a posteriori das analogias e metáforas. Classificação esta que permitiria descobrir outras características dessas figuras de linguagem e melhorar os seus usos nos livros didáticos ou em sala de aula.

Os dados e conclusões aqui apresentados podem contribuir para o ensino de Física, uma vez que ajudam educadores a perceberem as analogias e metáforas presentes nos capítulos de Física Moderna. A pesquisa pode, inclusive, ser ampliada para outros capítulos a fim de uma comparação entre eles. Sugere-se, também, que se investiguem os efeitos das analogias e metáforas presentes nos livros quando aplicadas em ambientes reais de ensino. Só assim, é possível fazer conclusões sobre seus benefícios ou malefícios.

\section{$\underline{\text { Referências }}$}

ANDRADE, A. C. S. et al. Analogias e metáforas no ensino e aprendizagem do conceito de átomo: breve análise em livros didáticos. Scientia Plena, v. 10, n. 4, 2014.

ANDRADE, B. L. de; ZYLBERSZTAJN, A.; FERRARI, N. As analogias e metáforas no ensino de ciências à luz da epistemologia de Gaston Bachelard. Ensaio - Pesquisa em Educação em Ciências, v. 2, n. 2, p. 182-192, jul./dez. 2000.

BARDIN, L. Análise de conteúdo. Lisboa: Edições 70, 2002.

BOZELLI, F.; NARDI, R. O uso de analogias e metáforas como recursos didáticos no ensino de física. Tecné, Episteme y Didaxis, n. 17, 2005.

BRASIL. Ministério da Educação. PNLD 2018: apresentação - guia de livros didáticos ensino médio. Brasília, DF: Ministério da Educação, Secretária de Educação Básica, 2017a.

BRASIL. Ministério da Educação. PNLD 2018: física - guia de livros didáticos - ensino médio. Brasília, DF: Ministério da Educação, Secretária de Educação Básica, 2017b. 
CHOPPIN, A. História dos livros e das edições didáticas: sobre o estado da arte. Educação e Pesquisa, v. 30, n. 3, p. 549-566, set./dez. 2004.

CURTIS, R. V.; REIGELUTH, C. M. The use of analogies in written text. Instructional Science, v.13, p. 99-117, 1984.

DUARTE, M. da C. Analogias na educação em ciências contributos e desafios. Investigações em Ensino de Ciências, v. 10, n. 1, p. 7-29, 2005.

DUIT, R. On the role of analogies and metaphors in learning science. Science Education, v. 75, n. 6, p. 649-672, 1991.

FERREIRA, E. B. M. O pesquisador e a produção científica da pós-graduação brasileira: tendências do debate sobre analogias. 2011. 285 f. Dissertação (Mestrado em Educação Tecnológica) - Centro Federal de Educação Tecnológica de Minas Gerais/CEFET-MG, Belo Horizonte.

FERREIRA, E. B. M.; GONÇALVES, I. A. Produção científica brasileira: tendências do debate sobre analogias. Enseñanza de las Ciencias, v. extra, p. 1240-1245, 2013.

FERRY, A. da S.; NAGEM, R. L. Analogias \& contra-analogias: uma proposta para o ensino de ciências numa perspectiva bachelardiana. Experiências em Ensino de Ciências, v. 3, n. 1, p. 7-21, 2008.

GLYNN, S.M. Explaining science concepts: a teaching-with-analogies model. In: GLYNN, S.M.; YEARNY, R.H.; BRITTON, B.K. (Orgs.). The Psychology of Learning Science. Hillsdale (EUA): Lawrence Erlbaum, 1991. p. 219-240.

GODOY, L. A. Sobre la estructura de las analogías en ciencias. Interciencia, v. 27, n. 8, ago. 2002.

GONZÁLEZ, M. B. G. La analogía y su presentación en los libros de texto de ciencias de educación secundaria. Enseñanza de las ciencias, v. extra, 2005.

HOFFMAN, R. R.; KEMPER, S. What could reaction-time studies be telling us about metaphor comprehension? Metaphor and Symbolic Activity, v. 2, n. 3, nov. 2009.

LAKOFF, G.; JOHNSON, M. Metaphors we live by. Chicago: University of Chicago Press, 2003.

LEITE, A. E.; GARCIA, N. M. D.; ROCHA, M. Tendências de pesquisa sobre os livros didáticos de ciências e física. In: CONGRESSO NACIONAL DE EDUCAÇÃO, X, EDUCERE, 2011, Curitiba. Anais... Curitiba: PUCPR, 2011, p. 11739-11751.

MONTEIRO, I. G.; JUSTI, R. S. Analogias em livros didáticos de química brasileiros desti- 
nados ao ensino médio. Investigações em Ensino de Ciências, v. 5, n. 2, p. 67-91, 2000.

MOURA, H. Vamos pensar em metáforas? São Leopoldo: Editora Unisinos, 2012.

MOZZER, N. B.; JUSTI, R. "Nem tudo que reluz é ouro": uma discussão sobre analogias e outras similaridades e recursos utilizados no ensino de ciências. Revista Brasileira de Pesquisa em Educação em Ciências, v. 15, n. 1, 2015.

NAGEM, R. L.; CARVALHAES, D. de O.; DIAS, J. A. Uma proposta de metodologia de ensino com analogias. Revista Portuguesa de Educação, v. 14, n. 1, 2001, p. 197-213.

OLIVEIRA, D.C. Análise de conteúdo temático-categorial: uma proposta de sistematização. Revista de Enfermagem da UERJ, Rio de Janeiro, 2008, v. 16, n. 4, p. 569-576.

OTERO, M. R. ¿Cómo usar analogías en clases de física? Caderno Catarinense de Ensino de Física, v. 14, n. 2, p. 179-187, ago. 1997.

PÁDUA, I. C. A. Analogias, metáforas e a construção do conhecimento: por um processo ensino-aprendizagem mais significativo. In: REUNIÃO ANUAL DA ANPED,26, 2003, Poços de Caldas. Anais... Rio de Janeiro: 2003.

PYNTE, J. et al. The time-course of metaphor comprehension: an event-related potential study. Brain and Language, v. 55, n. 3, p. 293-316, dez. 1996.

ROSA, C. T. W. da; CÓTICA, R. P.; PEREIRA, L. H. Analogias no estudo de eletricidade nos livros didáticos de física. Revista Electrónica de Enseñanza de las Ciencias, v. 15, n. 3, p. 363-379, 2016.

SARDINHA, T. B. Metáfora. São Paulo: Parábola Editorial, 2007.

SILVA, C. A. de S.; MARTINS, M. I. Analogias e metáforas nos livros didáticos de física. Caderno Brasileiro de Ensino de Física, v. 27, n. 2, p. 255-287, ago. 2010.

SILVA, L. L. da; ALMEIDA, M. J. P. M. de. Prós e contras da linguagem analógica segundo pesquisadores brasileiros: um estudo mediante a análise de publicações em revista científicas. Enseñanza de las Ciencias, v. extra, p. 3614-3618, 2009.

THIELE, R.B.; TREAGUST, D.F. The nature and extent of analogies in secondary chemistry textbooks. Instructional Science, v. 22, p. 61-74, 1994.

ZAMBON, L. B.; PICCINI, I. P.; TERRAZZAN, E. A. Comparando a utilização de analogias em livros didáticos para a educação em ciências. In: ENCONTRO NACIONAL DE PESQUISA EM EDUCAÇÃO EM CIÊNCIAS, VII, 2009, Florianópolis. Anais... Florianópolis: ABRAPEC, 2009. 